\title{
Not aid, but trade - an application of ARDL bound test for Pakistan economy
}

\author{
Muhammad Ahmad Mazher ${ }^{1 *}$, Jauhari Dahalan ${ }^{2}$ \\ Business School, University Kuala Lumpur (UniKL), Malaysia ${ }^{1,2}$ \\ muhammad.mazher@s.unikl.edu.my ${ }^{l^{*}}$,jauhari@unikl.edu.my ${ }^{2}$
}

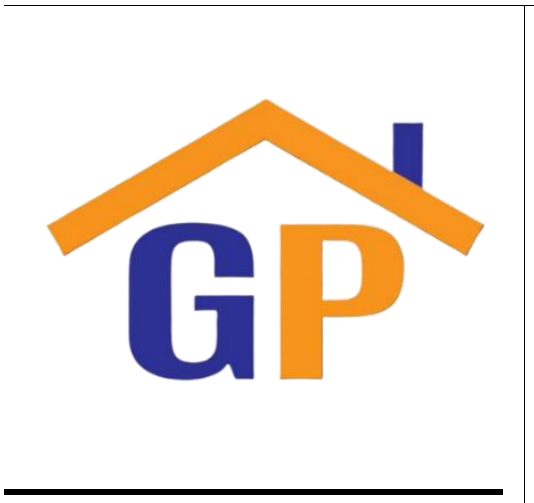

Article History

Received on 16 May 2020

$1^{\text {st }}$ Revision on 4 July 2020

$2^{\text {nd }}$ Revision on 9 July 2020

Accepted on 10 July 2020

\begin{abstract}
Purpose: Our research study aimed to analyze the statement of the proverb 'Not-Aid, but-Trade,' for the economy of Pakistan over 1970-2018 based on time-series data collected from the World Development Indicators - World Bank.
\end{abstract}

Research Methodology: Through evaluation of the theoretical and empirical literature, we estimate the influence of official development assistance, trade openness, foreign direct investment, inflation, and gross capital formation on the gross domestic product of Pakistan. To accomplish the required concerns, we implied the Unit-Root test, and the Autoregressive Distributed Lag Model Bound analysis.

Results: No significant relationship revealed between inflation and official development assistance. In contrast, the openness of trade and foreign direct investment shows a significant positive relationship with the gross domestic product of Pakistan. Similarly, gross capital formation has a negative but significant connection with the gross domestic product of Pakistan. For the short-run period, trade openness, foreign direct investment, and inflation impart to a positive and significant relationship; however, gross capital formation presents a negative but significant linking with gross domestic product.

Limitations: Our study covers the Pakistan economy time-series data over the 1970-2018 period.

Contribution: Our study is helpful for the Pakistani economic policy formation, particularly useful for academics and researchers to understand the basic concept related to 'not-aid but-trade' philosophy.

Keywords: GDP, ODA, Trade, GCF, Inflation

How to cite: Mazher, M. A., \& Dahalan, J. (2020). Not aid, but trade - an application of ARDL bound test for Pakistan economy. International Journal of Financial, Accounting, and Management, 2(1), 51-64.

\section{Introduction}

A slogan in the endowment of open-minded trade recognizes as 'trade, not aid.' This slogan designates a craving to purchase or acquisition products from developing countries rather than charitable they aid. Supporters of 'trade, not aid' believes that it signifies a new viable property and a lesser amount of dependence and procedure of growth and progress. According to Taimur Hassan (2013), afterward, freedom of the Islamic Republic of Pakistan has been concerned with treaty political and economic instability and has been hoping for aid and a variety of other forms of capital inflows. However, due to unreliable economic policies, countless people are frightened into the statuses of the poor, and then the country has not been capable of easing them. According to the World Bank (2018), trade is dominant and crucial toward ending world insolvency. Nations that are open to international trade have a focus on growing quicker, modernizing, expanding output, and deliver advanced gain then supplementary prospects to their peoples. Trade-openness puts rewards together to less-income family circle by 
providing customers a lot of value-effective products and services. Incorporation through the trade to the world economy and world value-chains supports ambition economic development also condenses poverty regionally, however, as internationally. The World Bank Group's activities in nations comprised of Bosnia and Herzegovina, Macedonia, and Indonesia had formed crosswise trade boundaries informal, formed logistic or provision services masses of consistent and competent producers for custom clearing. According to the World Bank, poverty statistics of Pakistan cut-down subsequently $64.3 \%$ to $29.5 \%$ from 2002-2014. Poverty headcount quantitative relation at $\$ 1.90$ on a commonplace (2011 PPP - \% of population) $6.1 \%-3.9 \%$ throughout $2013-2015$. The country has formed a considerable and actual imperative improvement in dropping poverty conditions giving it the $2^{\text {nd }}$ lowest headcount poverty condition rate in South Asia. Throughout 2005, almost 24.3\% of the entire population of the country survives underneath the national poverty line. While throughout 2015 the proportion of the working population lower \$1.90 PPP on a day is 3.9\%. in step with the Asian Development Bank (2019) and Pakistan Economic Survey (2017), illustrate that people existing underneath the poverty line settled to $24.3 \%$ throughout $2015-2016$ as of 50.4\% throughout 2005-2006.

Several developing economies inside the globe mock as weak not as they do not formulate adequate wealth, however because of their gain (incomes) misused to understand the consumption necessity of their peoples and so a smaller amount left as saving assets. Because of a lesser amount of savings, their investments to boot continue very low, and in due course, the process of growth in economy remains at little ranks, which is ill-famed as poverty-trap. Thus, the conventional unintended probability left for these developing economies includes external borrowing (foreign debt) and ODA (Official Development Assistance). This corroborative and funding aid to moderate the saving-investment (Saving < Investment) gap and provision for the deed of economic growth process objectives. ODA typically familiar with as 'foreign aid' (Aid inside the broader type of development facilitate of that ODA is single slice). It contains a supply of money settled from public divisions inside the custom of aid, debt, and grants (grants are capitals implicit by one party to another, for non-profit organizations like health and education, etc.). The ODA is decisively distinct over the OECD and DAC as concessional finance delivered by its partners to preserve the well-being and economic development of an allowable list of developing nations. The ODA is distinctive and exclusive in its responsiveness to insolvency. Whereas expressions are habitually using interchangeably, aid inside the broader assortment of development facilitates that ODA is one portion. The line of outlay $0.7 \%$ of GNI on ODA was at the start accomplished throughout 1970 and reorganized various times after, containing in 2005 by the $15 \mathrm{EU}$ member states. All-inclusive total ODA has developed from nearly USD 40 billion to USD 128 billion from the 1960s to 2012 severally. Almost 2/3 ${ }^{\text {rd }}$ of the ODA initiate from five G8 republics comprising the US, UK, Germany, France, and Japan that are increasingly prominent donors or contributors by volume.

Trade could be a long-term foundation for international collaboration. The opposite partner in a trading relationship is probably going to represent in the progress market-place for products or services. Therefore, once a developing country has the competence to have collaboration in trade with another country, there is a prevailing prospect that trade can flourish into an associate degree in development trading partnership. It permits a stable base for a flow of money or product into the developing country, mostly separately of whether or not the developed country is doing well or badly economically at a specified instant. It can equate to the stream of aid. It tends to be less expected, both as a consequence of it has influenced by political motives and because it is quite temporary. So if the developed country goes through a revolting economic phase, the aid budget makes an upfront target for a reduction in expense. According to WTO and OECD (2011), the commencement of the $21^{\text {st }}$ period has not exposed the extermination of insolvency over a trade-induced economic development and evolution. Nevertheless, if this has not stimulated adjustment within the predominant supposed economic information, that perceives trade employing a solid apparatus of economic growth. The schema has remained re-positioned towards stress change, globalization, insolvency decrease, and sustainability to revive the Doha Round negotiation practice. 
Laird (2007) opposed that impediment succeeding the usage of Uruguay round nonappearance of the segment on unmistakable and qualification direct delays undiscovered affirmations on the levy and share free activity for developing nations then the expanding exact examinations giving verification on welfare dead from potential Doha packages quick to the inclination among the methodology progressed other than creating nations were exaggerated by the WTO trade sessions. Likewise, Hoekman \& Nicita (2010) stated, the world recession 2008 2010 and food and energy disasters were foremost obstacles among the insolvency reduction schema, that practices slice of the millennium assertion, upholding the appreciation. Whereas not key move, many of the MDG goals are probable remains overlooked in entire constituencies.

According to WTO (2019), the aid for trade international review 2019 will become apparent itself from July 3 to July 5 at the world organization at a lower place, the theme 'Supportive Economic Variation and Management for Comprehensive, Property Development over Aid for Trade.' Through talking about the supply-side competence and trade connected infrastructure limitations of developing, and particularly LDCs (Least developed countries), aid intended for Trade can ease the event of the 2030 schema for property development. Aid for trade intentions to form trade a great deal of wide-ranging and patterned that its boundaries are outspread any and broader. The utmost focus in 2019, however, trades can somewhat contribute to economic broadening and management administration. The primary intention of this paper is to conclude the significance of trade concerning aid (ODA) for achieving the objective of economic development and growth for any weak economy like Pakistan. It was driven to evaluate whether trade-not-aid implies a re-orientation among the leading hypothesis. It may selfcontained a re-framing of the conventional approach that trade-openness is only meant onward for any nation following to progress.

According to Hoekman and Njinkeu (2007), the summit of the trade and development program ensued exclusively recently. Various networks and constituencies propelled conventionally aid-trade techniques. Who displayed changed institutions The GATT additionally the WTO on the one hand, and progress interventions (agencies) on the opposing? Therefore, this state of the globe continues to be one where aid and trade are overcoming in the direction of wholly different countries. Consequently, aid and trade information appears in the main as alternates. Literature review determination delivers a general plan meant for economic theories regarding development, growth, and trade. Dawn News (2019) reported during a speech at the United States Peace Institute, Prime Minister Imran Khan reassured the audience that Pakistan is pursuing a "dignified relationship with the United States" that is not impeded by acquiring or withdrawing aid. During his speech, Imran Khan also openly declared that aid is one of the most significant courses for Pakistan. He also conveys the message to US higher official authorities that Pakistan is no more interested in their aid programs; however, trade activities and expansion. Important objective towards determine framework intended for investigation, ODA (Aid) could be a curse whereas trade is that the factual soul (trade-not-aid).

The originality and uniqueness of our study based on three crucial arguments. Primarily, our study based on a prime minister of Pakistan spoken actual words that we transformed into an economic language, and empirically demonstrate through econometric techniques and demonstrate that his opinions concerning his country are precise. Furthermore, we implied a unique combination of economic variables with extensive time-series data set consist of 48-years that are not applied before by any other researcher for Pakistan. Finally, the econometric technique we used for the estimation of the model is entirely different from prior studies. Hence, the intention and objective of our study patterned whether the proverb 'Not-aid, but-Trade' is concerning and valid for the Pakistani economy of not? More precisely, is there aid and trade performing the significant and robust role for development and economic growth for Pakistan or not?

\section{Prerequisite Hypothesis}

The following hypothesis needs to examine for endorsing the proverb 'Not-aid, But-trade.'

i. $\quad \mathrm{H}_{01}$ : There is a positive and significant relationship between trade openness and economic growth in Pakistan.

$\mathrm{H}_{11}$ : There is a negative and insignificant relationship between trade openness and economic growth in Pakistan. 
ii. $\mathrm{H}_{02}$ : There is a negative and insignificant relationship between ODA and economic growth in Pakistan.

$\mathrm{H}_{12}$ : There is a positive and significant relationship between ODA and economic growth in Pakistan.

iii. $\mathrm{H}_{03}$ : There is a positive and significant relationship between FDI and economic growth in Pakistan.

$\mathrm{H}_{13}$ : There is a negative and insignificant relationship between FDI and economic growth in Pakistan.

iv. $\mathrm{H}_{04}$ : There is a positive and significant relationship between GCF and economic growth in Pakistan.

$\mathrm{H}_{14}$ : There is a negative and insignificant relationship between GCF and economic growth in Pakistan.

\section{Literature review and hypothesis development}

According to Wood (1994), recognition about the prerequisite for fundamental qualitative standard and collective disciplines assumed the various aim and interests considered very important in the study of development. DAC (Development Assistance Committee - under the OECD) recognized as a preliminary forum with the motive to imitating consents between agencies related to growth in regards to statistical norms and their definitions. According to OECD (1992), there is a significant feat by DAC to develop and adapt the explanation of official development assistance (ODA) prudently. This definition directs to a clear and transparent picture of ODA policies and facilitates donor agencies or countries to set their targets for increasing their Aid (ODA) exertions.

Usually, ODA notorious as foreign aid, that is consists of capital resources that are transforming from abroad or public sides to free the country comprise of grants, loans at concessional terms to developing countries. Foreign aid effectiveness evaluated and assessed by many researchers empirically with motives to determine the impact in developed as well as developing economies. The research studies at micro-level implying cost-benefit analysis led to viewpoint support of the effeteness of foreign aid. Conversely, consequences presented through various studies presented at the macro-level called crosscountry regression analysis revealed ambiguous outcomes. Hence, due to micro-level and macro-level analysis, the Mosley et al. (1987) notion it as his contribution micro-macro-paradox. More, there is a difference between two concepts named official development assistance (ODA) and official development finance (ODF) described by the World Bank. The World Bank (1998) defined the concept of ODA as the sub-set of ODF while ODA consists of grants and concessional debt, which have at least $25 \%$ component as of grant. The loan in which at least $25 \%$ element included as grant assumed to be adequately concessional and to be comprised in ODA, whereas estimated at a $10 \%$ discount rate. In other words, ODA involves the various costs like the cost to the donor on project or aid program, technical cooperation, debt forgiveness that are not reported already as ODA, emergency and food aid, and management related expenditures.

The reference during development, economic progress, and trade has been the topic of dialogue in research scholars, worldwide and NGOs, and policy-makers for a substantial period. Conferring to Rahnema \& Bawtree (1997), throughout the $19^{\text {th }}$ Century, the notion 'development' was linked philosophies of stewardship and also an improvement from poverty and barbarism to prosperity and civilization. Chon (2004) and Easterly (2009) described that transformation theory strains that expansion may be a linear stage-by-stage conversion of entirely 'classical' Agri; otherwise, farming societies into modern societies through economic growth. That contains antique replacement practices with western norms as well as organizations over international economic relations. Rist (2007) argued that besides clear definition unreachability, the development hollow involved robust philosophies in whatever the opinion is intending to advise, tempting individuals who desire progress in their socioeconomic living circumstances and individuals with an essential requirement toward global social detachment. More, it is conferred by Rist that growth turns into a recital word whereby any measure, allowing FDI, raising or depressing trade barriers, or education and coaching activities, was adequate and legalize by privileges. It was fastened to uplift the lives of impoverished individuals. 
According to Smith (2008), the classical economic study forecasts that a nation develops over the specialization or concentration of labour (L) as well as capital (K) accumulation. Specialism proposes that countries vary in their aptitude to provide goods \& services, and subsequently, they ought to target the products (goods) that they will yield more proficiently. Therefore, as per classical theory, the essential factors of the production confirm relative advantage, and likewise, the export structure of an economy is labor (L), capital (K), and natural resources (N). Smith (2008) implicit that, more significant the market-place, the larger capacity of individuals to exploit their expected tendency meant for barter and exchange. They were conferring to Lwehabura \& Stilwell (2008), Ricardo's intricate impression within comparative advantage theory. They suggested if a transaction was to take place between nations, at that time, those countries could return economically from trade through focused on the invention of the goods at that they are comparatively more thrilled than their corresponding trading allies.

The neo-classic sentiment with the end goal of venture/capital accumulation is exhibiting over the model of Solow-Swan. The essential and noteworthy gauge was that a particular economy would at long last ability zero progression in per-capita earnings. Therefore, diminishing marginal returns (DMR) on capital will compel GDP development to remain equal to the population development and technology development. It decided inside the effort of Romer (1989) who predicted that notwithstanding the underlying ascent in GDP through the rebuilding of resources or assets to extra enterprising and inventive segments long projections for improvement in a closed-economy are in the end decided through the resources that allowed towards the sector that produces new intermediate endeavours or instruments. Henceforth Romer's model uncovered exceptionally enthusiastic results for the valuable impacts of open-trade, which may raise the speed of technological progression. From that point, product development, through the broadening of the market-place expected for moderate or capital products, giving a lively and solid comprehension of why import-substitution approaches are ruling by exportpromotion.

Yiew \& Lau (2018) determine the description part and, therefore, the influence of ODA proceeding to GDP, implying 95 evolving nations. The scholars conjointly embrace FDI and population, consider as the control variables. Though panel study, outcomes specify U-shaped connection occurs amid ODAGDP, already discussed by Wamboye (2012). Primarily, ODA destructively affects the growth of nations over time; it absolutely subsidies to GDP. More, study outcomes strongly backing each FDI and population are more substantial causes of GDP, demonstrate GDP is not as much of probably towards rely upon ODA. Firming the permissible context can crucial intended for targeted nations, whereas over-dependency trendy inflow of ODA would possibly cause adverse influences on the growth ultimately. Meaningfully, the efficient administration of ODA could make sure Sustainable Development Goals (SDG) accomplished. MM (2016) intends to examine and determine the influence of foreign aid on economic growth through implying Dynamic Ordinary Least Sq. (DOLS) technique. Subsequently, through the application of the "endogenous growth model" besides time-series data from 1976-2014. The researcher intends to initiate, foreign aid an adverse impression on economic growth.

Moreover, during short-run academics, foreign aid does not Granger Cause with GDP. Finally, consequences direct the government needs to reconsideration sort of ODA that's receive. A. Asongu \& C. Nwachukwu (2015) examines implications about an over-abundance of ODA dynamics proceeding difference accustomed human development for 53 African nations over 2005-2012. Through contemporary (modern or current) and non-contemporary (traditional) OLS, Fixed Effects (FE) and GMM methods with forwarding orthogonal deviations are using. Researchers conclude few outcomes comprising; first, the influences of aid dynamics with high degrees of substitution are optimistic include ODA for social structure, economic structure, productive sector, and multi-sectors. Second, the consequence of humanitarian aid is steadily negative across specifications and models. Third, the outcomes of program sustenance and action on debt are unclear as they become positive with the GMM method.

Mujahid, Begum, \& Noman (2016) discover connotation among export and economic progression for Pakistan over 1971-2013. Researchers employ GDP, imports, exports, and foreign direct investment (FDI) for their study. Through the application of the ARDL and ECM approach, it is concluded the cause $\&$ effect link amid the exchange rate and FDI. Pakistan has numerous possibilities for enhancing 
exports, for that there is a prerequisite to diminish trade barriers and restrictions like import and export quotas etc. more, Pakistan needs to implement policies immediately to support logistics and facilitates trade. Keho (2017) analyzes association among trade-openness and GDP and conclude contradictory and uncertain results. It might perceive as a deficiency part of capital stock and labor with-it tradegrowth affiliation. The study grasps the impression of trade-openness on GDP used for Cote d' lvoire 1965-2014 out of a multivariate context together with capital stock, labor, and trade-openness by methods for regressors. Keho infers the auto-regressive distributed lag (ARDL) bounds test for evaluating co-integration while Toda \& Yamamoto (1995) for investigation about causality assessment. Results strengthen constructive consequences on GDP through trade-openness in the short and long-run. Moreover, Keho revealed a positive, robust adjusting bond among tradeopenness and capital-formation in authorizing financial and economic growth.

According to Burnside \& Dollar (2000), there is a relationship that exists between developing economies and their fiscal, monetary, and trade policies. Through a panel study of 56 economies data, they revealed that excellent and robust systems revealed a significant impact of aid to economic growth comprise robust fiscal policy, monetary policy, and trade strategies in developing economies. While poor economic strategies directed to no relationship between aid and growth. Five out of six economies, there is a negative and significant long-run relationship that exists between aid and economic growth. In contrast, a positive and significant relationship revealed for Togo, according to Malik (2008). The outcome analysis exposed that the five countries revealed negative and considerable relationship having poor and bad governmental policies, aid instability, and low level of domestic saving level. According to Javid \& Qayyum (2011), aid effectiveness under debate the interactive effect of aid and policy on sustainable economic growth. Through the ARDL Co-integration method, over 1960-2008 data, empirical estimations revealed a negative relationship between RGDP and foreign aid during the opinion of the aid-policy interactive term. The study exposed crowding in effect between sectorial aidspending within sectors of education and agriculture.

Nonetheless, crowding out effects revealed in transport, communication, and construction sectors. Hence, in this scene, there is a negative relationship in sectorial aid impact on sector spending. With debt-servicing expenditures, Aid significantly affected while insignificant spending and services for security or defense motives. Wer (2015) studied through pragmatic observation analyses differential possessions among the trade-investment and economic process. The study disclosed that trade has a positive impact on economic progression.

Nevertheless, empirical outcomes report optimistic effects among trade-growth intended for both developed and developing nations whereas inconsequential for least developed countries covering most part to contain African republics. More scholar exposes that trade may be an essential and vital deciding issue of FDI across entirely nation's crews besides its proposed by a scholar that LDCs and preponderantly African countries ought to be reworked so employing accomplishing higher progress paybacks. Zahonogo (2017) evaluated the sources through trade-openness stimuli developing economies and Sub-Saharan Africa (SSA). Over 1980-2012, through 42 SSA nations, researchers implied a dynamic growth model. Through the application of the PMG (Pooled mean group) technique, precise empirical outcome direct that trade threshold exists under greater trade-openness sympathetically affect growth and higher than trade consequences on growth drop subsists. It also exposed the Laffer inverted U-shaped curve (Laffer trade curve) that is robust to fluctuation in tradeopenness measures and to exchange or distinctive models. Stipulations, meaning the non-break-capacity of the association between economic growth and trade-openness for Sub-Saharan countries. Semančíková (2016) examines the association between trade, trade-openness, and macroeconomic performance. By implying descriptive as well as comparative analysis by reviewing substantial empirical research literature review throughout historical eras. Based on contemporary literature, the observed outcome directs to the positive influence of trade and trade - openness on macroeconomic variables. Henceforward, a primer of suitable trade strategies in any economy is a crucial source of its economic progress. 
Suwa-Eisenmann \& Verdier (2007) appraisals contemporary hypothetical empirical prose, which determines the connection between aid and trade. Inquiries concerning integral swap impacts at exertion. Analysts tend to differentiate upshots among aid-trade flows and trade procedures of the patron or supporter also because of receiver countries. Distinct concentration assumed on trade enabling otherwise aid for trade. According to the policy paper IMF (2007), aid for trade will support countries attempting to any take pleasure or benefits in the growing international market place by serving to deal with poorly performing infrastructure, establishments, and institutions. Unnecessary to mention, excellent and acute policies conjointly matter: trade liberalization, rising incentives for personal investment in trade, and reducing the cost and intensifying the standard of services. Market access/entree conjointly matters; consequently, a positive and effective conclusion to the Doha Round leftovers a high policy impartial. Hence, this paper highlights three tasks and proposes some areas for any survey including creating forcefulness support or pillar of country growth strategies, the substance the outstanding gaps in trade-related aid, and increasing the aid packet and making complete use of chance or opportunity to replenish or replace the International Development Association.

\section{Essential Terms and their Definitions}

Official Development Assistance (ODA)

Since 1981, the development assistance committee (DAC) measured movements of capital resources (external debt, aid) towards developing nations. ODA recognized as particular attention part in these flows, and during 1969, the DAC defined this concept first time and squeezed in 1972. It is a significant factor used to measure all aid targets as well as the performance of aid. According to the definition OECD (2018), the official development assistance grant equivalent estimate as of donor effort. The other flows of capital comprise grants and loans considered in estimations of ODA grant equivalent estimation denoted as ODA flows. It defines the flows towards countries and regions which are listing in the DAC list of ODA receivers. It comprises offered by official agencies like state, domestic local governments, bodies and to management or administration with the motive to economic development and welfare-being in developing economies as well as grants in which $45 \%$ (bilateral loans to the official of LDCs), $15 \%$ (bilateral loans to the official of LMICs), and 10\% for UMICs.

\section{Trade-Openness}

The total or sum of imports and exports, which are normalizing through GDP, is a notion as trade openness. According to Lane \& Milesi-Ferretti (2008) and Mishra (2007), there is a robust correlational relationship between bilateral equity investment and underlying patterns of trade. To accomplish accounting and to control overseas markets by trade and thus investment in external or offshore assets, investors considered more intelligent and capable. Constrained trade integration makes the cause of upturn in default risk - cross-border flows directly generated by trade transactions comprising trade credit, export insurance, and payment facilitation.

\section{Foreign Direct Investment (FDI)}

Direct investment from abroad into the reporting country recognized as a foreign direct investment (FDI). The total of equity capital, earnings from re-investments, and other kinds of capital inflow. It categorized cross-border investment-linked utilizing resident individuals who have control or management influence or significance degree to other residing economy businesses or enterprises.

\section{Inflation}

When the demand for products more than its supply usually leads to a rise in prices, this phenomenal price increasing known as inflation. Consumer price index (CPI) as determining inflation reveals the change as an annual percentage in average consumer cost of conquering bundle of goods $\&$ services, which may change or fix for some time like yearly. The Laspeyres method used to estimate for CPI.

\section{- Gross Capital Formation (GCF)}

The net change in inventories plus outlay on the addition to the fixed assets of the economy called gross capital formation or gross domestic investment. The fixed assets comprise plant, machinery, land development, roads construction, purchases of tools and equipment, schools, hospital, offices, railways, residential home privately, and commercial building, etc. while inventories comprise on the stock of 
goods held by companies to fulfil the temporary or unexpected requirements during production and work in progress. Net purchases or acquisitions of treasures or valuables included in capital formation.

\section{- Gross Domestic Product (GDP)}

The summation of gross value added through all inhabitant of country's producers plus product taxes, if any, minus subsidies, if any, which is not included in the value of product notion as the gross domestic product (GDP) at purchasers' prices. GDP estimated without depreciation deductions for invented resources and natural resources decline and humiliation.

\section{Research methodology}

Data for Gross Domestic Product (GDP), Trade-Openness, ODA, FDI, Inflation, besides, GCF was acquired as of World Development Indicators (WDI) for years 1970-2018 for Pakistan. Preceding towards the estimation, the ODA, GDP, FDI, GCF, and Inflation variables stood changed obsessed by a logarithmic arrangement. The few factors in the model, explicitly ODA, FDI, Gross domestic product, and Inflation have been widely suggested before the investigation, acknowledge each other, Bloom et al. (1998), Morrissey (2001), Cungu \& Swinnen (2003), Dalgaard et al. (2004), Rajan \& Subramanian (2008), Chih-Chiang \& Jyun-Yi (2008), Mitra \& Hossain (2013) and Galiani et al. (2016). Our model is expressing as pursues:

$\mathrm{GDP}=\mathrm{f}(\mathrm{ODA}$, Trade-Openness, FDI, Inflation, GCF $)$

Wherever GDP is the gross domestic product, ODA is the official development assistance (Aid), FDI is the foreign direct investment, inflation, and GCF is the Gross Capital Formation. ARDL bound test was implied to scrutinize the impression of ODA (foreign aid) and trade-openness on economic growth as follows:

$$
\text { GDP }=\beta_{0}+\beta_{1} \text { ODA }+\beta_{2} \text { Trade-Openness }+\beta_{3} \text { FDI }+\beta_{4} \text { Inflation }+\beta_{5} \text { GCF }+\varepsilon
$$

The connection between implicit variables combined in our research study was restrained through econometric approaches includes a unit-root test, Johansen co-integration test, and error correction model. Nelson \& Plosser (1982) showed that in macro-economic variable data, there is an issue of a unit root. Therefore, we lean towards imply unit root test thorough Philips and Perron test (PP) to check whether our data are stationary or not. In the initial step, we need to pattern the stationary of data, consequently the Philips \& Perron test. After accessing the PP test, ARDL to co-integration technique is suitable for this model. In the second step, we try to find a long-run bond among variables over applying ARDL co-integration developed by Pesaran \& Shin (1999) and ECM developed through Engle \& Granger (1987). There are many previous types of research in which these tests had applied primarily to check the long-run equilibrium condition. This econometric technique is using due to simplicity and relevance in time-series data, the ability to confirm stationary and confirm long as well as short-run association among the said variables. To estimate the ARDL approach and to avoid spurious results, all variables which taken need to be stationary. The Akaike Information Criterion (AIC), Schwarz Criterion (SC), and the Likelihood Ratio (LR) test implied to select the number of lags required in the ARDL test. If long-run co-integration proved, then we move to test the short-run equilibrium relationship. The main objective of ECM is it checks the speed of modification from the short-run to the long-run. The higher value of the coefficient of error correction term, the higher the speed of adjustment of the model it will be.

\section{Results and discussions}

The unit-root outcome based on the "Phillips-Perron test" (PP) is showing in the following table - 1;

\begin{tabular}{ccc}
\hline \multicolumn{3}{c}{ Table - 1 } \\
\hline Unit-root Test - Phillips-Perron Method \\
\hline Variables & Level & $1^{\text {st }}$ difference \\
\hline GCF $(\%$ GDP $)$ & 0.1973 & 0.0000 \\
\hline Inflation & 0.0295 & - \\
\hline FDI & 0.0029 & - \\
\hline
\end{tabular}




\begin{tabular}{ccc}
\hline GDP & 0.9353 & 0.0000 \\
\hline Trade Openness & 0.8033 & 0.0000 \\
\hline ODA per capita & 0.0059 & - \\
\hline
\end{tabular}

Through Phillips \& Perron (1988), unit-root outcomes direct towards the application of the ARDL bound test. According to Nkoro \& Uko (2016), this study analyses the problems encompassing the way co-integration techniques are functional, predictable, and interpreted within the context of the ARDL co-integration framework. The study demonstrates that the implementation of the ARDL co-integration technique does not need pre-tests for unit-roots, not like different techniques. Therefore, the ARDL cointegration technique is looked-for once addressing variables that integrated of various orders, I(0), I(1), or combination of each and robust once there is the single long-run relationship between the causal variables in a small sample size. However, this technique will crash in the presence of an integrated stochastic trend of I(2). To forecast exertion in un-usefulness, it is going to be best to assess unit-roots, although not as a necessary condition.

\begin{tabular}{ccc}
\hline \multicolumn{3}{c}{ Table - 2 } \\
\hline \multicolumn{3}{c}{ VAR Lag Order Selection - Criteria } \\
\hline Lag & AIC & SC \\
\hline 0 & -7.585380 & -7.342081 \\
\hline 1 & -14.51755 & $-12.81446^{*}$ \\
\hline 2 & -14.74252 & -11.57964 \\
\hline 3 & -15.02597 & -10.40330 \\
\hline 4 & $-16.25320^{*}$ & -10.17073
\end{tabular}

Table -2 indicates the lag-order selected by the various criterion techniques. According to above laglength criterion outcomes, the lag-length through SC criterion remains 1 while AIC criterion directing 4 as lag length criteria.

\begin{tabular}{lllll}
\hline \multicolumn{5}{c}{ Table - 3 } \\
\hline \multicolumn{5}{c}{ ARDL Bound Test } \\
\hline F-Bounds Test & $\mathrm{H}_{0}$ : No levels of relationship \\
\hline Test Statistic & Value & Sig. & $\mathrm{I}(0)$ & $\mathrm{I}(1)$ \\
\hline F- Statistic & 5.201046 & $10 \%$ & 2.08 & 3.00 \\
\hline $\mathrm{K}$ & 5 & $5 \%$ & 2.39 & 3.38 \\
\hline & & $1 \%$ & 3.06 & 5.15
\end{tabular}

Table -3 states ARDL bound test and the long-run relationship among the variables. When F-statistic value (5.201046) remains higher than the value of test statistic - I( 0$)$ and $\mathrm{I}(1)(2.39 \%$ and $3.38 \%)$ then, we can say that our model variables have a long-run relationship.

\begin{tabular}{ccccc}
\hline \multicolumn{5}{c}{ Table - 4 } \\
\hline \multicolumn{5}{c}{ ARDL Error Correction Regression } \\
\hline ECM Regression \\
\hline Variable & Coefficient & Standard Error & t-Statistic & Probability \\
\hline CointEq(-1) & -0.405377 & 0.059831 & -6.775314 & 0.0000 \\
\hline $\mathrm{R}^{2}$ & 0.853832 & Adj. $\mathrm{R}^{2}$ & 0.783268 \\
\hline Durbin-Watson stat & 2.352762 & & & \\
\hline
\end{tabular}

According to table - 4, If the error-correction (EC) coefficient is negative (-0.405377) and significant, it shows a long-run relationship exists between independent and dependent variables of the model.

\begin{tabular}{ccccc}
\hline \multicolumn{5}{c}{ Table - 5 } \\
\hline \multicolumn{5}{c}{ ARDL - Long-run Analysis } \\
\hline Levels Equation - Case 2: Restricted Constant and No-Trend \\
\hline Variable & Coefficient & Standard Error & t-Statistic & Probability \\
\hline Log ODA per capita & -0.021962 & 0.158983 & -0.138138 & 0.8913 \\
\hline Log Trade-Openness & 0.535079 & 0.133634 & 4.004059 & 0.0006 \\
\hline Log FDI & 0.211625 & 0.052863 & 4.003252 & 0.0006
\end{tabular}




\begin{tabular}{ccccc}
\hline Log Inflation & 0.132988 & 0.078283 & 1.698810 & 0.1028 \\
\hline $\log$ GCF(\%GDP) & -2.614800 & 0.517729 & -5.050518 & 0.0000 \\
\hline C & 6.860696 & 1.339051 & 5.123549 & 0.0000
\end{tabular}

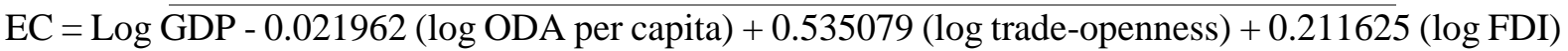
+ 0.132988 (log Inflation) - 2.614800 (log GCF-\%of GDP) + 6.860696

The above table -5 direct that ODA per capita and Inflation is having no significant relationship with GDP, while trade-openness and FDI revealing a significant positive association with GDP and can describe as, by increasing $1 \%$ in both variables, it may increase $0.535 \%$ and $0.211 \%$ respectively. More, GCF (\%GDP) having a negative but significant relationship and direct that by increase $1 \%$ in GCF (\%GDP) will make the cause of decrease by $2.614 \%$ in GDP.

\begin{tabular}{ccccc}
\hline \multicolumn{5}{c}{ Table - 6 } \\
\hline \multicolumn{5}{c}{ Chort-run Analysis Outcomes } \\
\hline Variable & Coefficient & Standard Error & t-Statistic & Probability \\
\hline Log ODA per capita & -0.008903 & 0.064543 & -0.137935 & 0.8915 \\
\hline Log Trade-Openness & 0.216909 & 0.098606 & 2.199755 & 0.0381 \\
\hline Log FDI & 0.085788 & 0.028132 & 3.049436 & 0.0057 \\
\hline Log Inflation & 0.053910 & 0.024400 & 2.209462 & 0.0374 \\
\hline Log GCF(\%GDP) & -1.059980 & 0.252176 & -4.203328 & 0.0003 \\
\hline C & 2.781169 & 0.720469 & 3.860222 & 0.0008
\end{tabular}

According to table -6 , under the short-run period, trade-openness, FDI, and inflation revealing positive and significant relationships while GCF (\%GDP) showing a negative significant and, ODA per capita, revealing negative and non-significant relationship with GDP.

\section{Table - 7}

\begin{tabular}{cccc}
\hline \multicolumn{4}{c}{ Breusch - Godfrey Serial Correlation LM Test } \\
\hline F-Statistic & 0.839575 & Prob. F(3,20) & 0.4881 \\
\hline Obs* R $^{2}$ & 4.921411 & Prob. Chi-Square (3) & 0.1776 \\
\hline
\end{tabular}

Above table -7 representing serial correlation LM test. If the estimated value of Prob. Chi-Square value (0.1776) is higher than the 5\% (0.05) level of significance, then our estimated model not having any serial correlation problem.

\begin{tabular}{llll}
\hline \multicolumn{4}{c}{ Table - 8 } \\
\hline Heteroscedasticity Test: Breusch-Pagan-Godfrey Method \\
\hline F-Statistic & 0.409209 & Prob. F(20,23) & 0.9762 \\
\hline Obs*R $^{2}$ & 11.54764 & Prob. Chi-Square (20) & 0.9308 \\
\hline Scaled Explained SS & 3.604496 & Prob. Chi-Square (20) & 1.0000 \\
\hline
\end{tabular}

According to table 8, the estimated Prob. Chi-Square value (0.9308) is higher than the 5\% (0.05) level of significance indicates that there is no heteroscedasticity issue exit in our model.

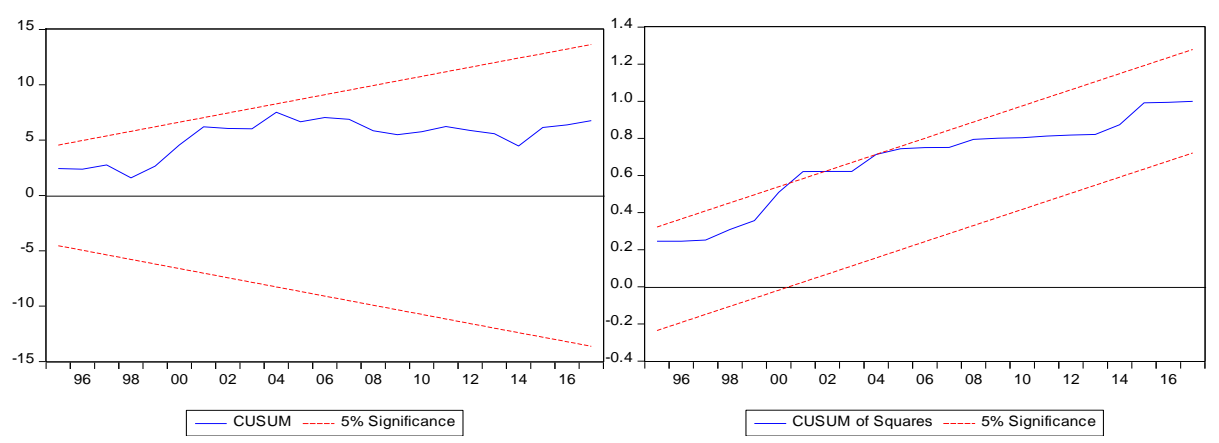

(Diagram - A) 
According to diagram - A, in statistical quality control, the CUSUM (or cumulative sum control chart) is a serial analysis technique established by E. S. Page of the University of Cambridge. It typically used for monitoring change detection. The rule of thumb can describe as if the estimated line (blue) is inside of red lines (critical lines), then we can say that our statistical model is fit and having robust outcomes.

\section{Summary of results and discussions}

All-in-all, ARDL error-correction regression model revealed the presence of a long-run relationship between independent and dependent variables comprise of ODA, trade-openness, FDI, inflation, GCF, economic growth, respectively. For the long-run period, our outcomes direct the negative and insignificant relationship between ODA and economic growth for Pakistan. In contrast, a positive and significant relationship revealed between trade-openness and FDI. More, inflation exposed insignificant, and GCF revealed a negative but significant relationship with economic growth for Pakistan's economy. In short-run, the economy of Pakistan showed a negative and irrelevant relationship between ODA and economic growth again, although GCF having a significant but negative relationship. More, trade-openness, FDI, and inflation exposed positive and significant relationships with the economic growth of Pakistan.

Hence, it is concluding that aid exposed a negative and insignificant impact. At the same time, the tradeopenness revealed a positive and significant impact throughout the short-run and long-run periods for Pakistan's economy over the period. Many other scholars and even the World Bank also snapshots in the same line as per our outcomes. For instance, the World Bank (2018) stated that trade having a dominant role and can play a significantly vital role in ending global indebtedness. The nations having trade-openness can focus on their economic growth rapidly. More, Wer (2015) disclosed that trade has a positive impact on economic progression. Yiew \& Lau (2018) determine the description part and, therefore, the influence of ODA proceeding to GDP, implying 95 evolving nations. The scholars conjointly embrace FDI and population, consider as the control variables. Though panel study, outcomes specify U-shaped connection occurs amid ODA-GDP, already discussed thru Wamboye (2012). Similarly, MM (2016), A. Asongu \& C. Nwachukwu (2015), and Javid \& Qayyum (2011) also revealed the negative impact of aid on growth. Burnside \& Dollar (2000) concluded that for developing nations, aid showed positive impact if and only if their fiscal, monetary, and trade policies will be functional and attractive, otherwise the effect of aid may be revealed negative implications.

\section{Conclusion and implications}

The final empirical decisions revealed that a long-run relationship exists among implicit variables through ARDL Bound test F-statistic value and ARDL error correction regression outcomes. The longrun ARDL analysis shows that both official development assistance per capita and inflation devise no significant relationship with the GDP of Pakistan. Whereas trade-openness and foreign direct investment, revealing a positive and significant relationship with the GDP of Pakistan. It describes that by increasing $1 \%$ in both variables, the GDP of Pakistan can increase by $0.535 \%$ and $0.211 \%$, respectively. More, gross capital formation as \% of GDP revealed a negative but significant relationship, which designates by a $1 \%$ increase in this economic factor, make the cause of the decrease by $2.614 \%$ in the GDP of Pakistan.

Furthermore, short-run outcomes conclude that official development assistance per capita remained negative and insignificant. While trade-openness, foreign direct investment, and inflation revealing a positive and significant relationship with the GDP of Pakistan. Therefore, based on empirical outcomes, our study indicates that under the short-run and long-run, official development assistance is not beneficial. However, trade-openness significantly and positively impacted on GDP of Pakistan. Hence, the slogan that 'not-aid, but-trade' is unconditionally valid for Pakistan's economy.

Based on the above conclusions, it suggested that over the short-run and long-run periods, the government of Pakistan prerequisites expand the trade volume for augmentation in their GDP. The trade stability must be optimistic means imports must be lesser than exports of the country, which leads to the rise in the country's income/revenues. For the long-run period, Pakistan needs to control inflation and reduce or eliminate the volume of official development assistance per capita assistance because 
both economic aspects are destructive to the economy. It also endorses that under the long-run, foreign direct investment (FDI) is also very valuable for the Pakistan economy, and its rise indicates growth in the GDP of Pakistan. In conclusion, it is the vigorous recommendation that official development assistance (aid) is not virtuous but trade.

\section{References}

A. Asongu, S., \& C. Nwachukwu, J. (2015). Foreign aid and inclusive development: Updated evidence from Africa, 2005-2012 [AGDI Working Paper]. African Governance and Development Institute.

Asian Development Bank. (2019, May 6). Poverty in Pakistan [Text]. Asian Development Bank. https://www.adb.org/countries/pakistan/poverty

Bloom, D. E., Sachs, J. D., Collier, P., \& Udry, C. (1998). Geography, demography, and economic growth in Africa. Brookings Papers on Economic Activity, 1998(2), 207-295. JSTOR. https://doi.org/10.2307/2534695

Burnside, \& Dollar. (2000). Aid poilitic and growth. The American Economic Review, 90(5), 847868.

Chih-Chiang, H., \& Jyun-Yi, W. (2008). Does foreign direct investment promote economic growth? Evidence from a threshold regression analysis. Economics Bulletin. https://core.ac.uk/reader/6420614

Chon, Theodore. H. (2004). Global political economy (6th ed.). Longman Pearson Education, Inc.

Cungu, A., \& Swinnen, J. (2003). The impact of aid on economic growth in transition economies: An empirical study. In LICOS Discussion Papers (No. 12803; LICOS Discussion Papers). LICOS - Centre for Institutions and Economic Performance, KU Leuven. https://ideas.repec.org/p/lic/licosd/12803.html

Dalgaard, C., Hansen, H., \& Tarp, F. (2004). On the empirics of foreign aid and growth. The Economics Journal. https://onlinelibrary.wiley.com/doi/10.1111/j.1468-0297.2004.00219.x

Dawn News. (2019, July 23). Aid has been one of the biggest curses for Pakistan: PM Imran. DAWN.COM. https://www.dawn.com/news/1495748

Easterly, W. (2009). Can the West save Africa? Journal of Economic Literature, 47(2), 373-447. JSTOR. https://www.jstor.org/stable/27739927

Engle, R. F., \& Granger, C. W. J. (1987). Co-integration and error correction: Representation, estimation, and testing. Econometrica, 55(2), 251-276.

Galiani, S., Knack, S., Xu, L., \& Zou, B. (2016). The effect of aid on growth: Evidence from a quasiexperiment. Journal of Economic Growth, 22. https://doi.org/10.1007/s10887-016-9137-4

Hoekman, B., \& Nicita, A. (2010). Assessing the Doha Round: Market access, transactions costs and aid for trade facilitation. The Journal of International Trade \& Economic Development, 19(1), 65-79. https://doi.org/10.1080/09638190903327476

Hoekman, B., \& Njinkeu, D. (2007). Aid for trade and export competitiveness: New opportunities for Africa. Cambridge, Cambridge University Press., 32.

IMF. (2007). Aid for trade-harnessing globalization for economic development. https://www.imf.org/en/Publications/Policy-Papers/Issues/2016/12/31/Aid-for-TradeHarnessing-Globalization-for-Economic-Development-PP4230

Javid, M., \& Qayyum, A. (2011). Foreign aid and growth nexus in Pakistan: The role of macroeconomic policies (PIDE-Working Paper 2011:72). Pakistan Institute of Development Economics. https://econpapers.repec.org/paper/pidwpaper/2011_3a72.htm

Keho, Y. (2017). The impact of trade openness on economic growth: The case of Cote d'Ivoire. Cogent Economics \& Finance, 5.

Laird, S. (2007). Aid for trade: Cool aid or kool-aid? United Nations Conference on Trade and Development.

Lane, P. R., \& Milesi-Ferretti, G. M. (2008). The drivers of financial globalization. American Economic Review, 98(2), 327-332.

Lwehabura, M. J., \& Stilwell, C. (2008). Information literacy in Tanzanian universities: Challenges and potential opportunities. Journal of Librarianship and Information Science. https://doi.org/10.1177/0961000608092553 
Malik, A. (2008). Challenging Dominance: Symbols, Institutions, and vulnerabilities in Minarchist Political Islam. The Muslim World, 98(4), 502-519. https://doi.org/10.1111/j.14781913.2008.00243.x

Mishra, P. (2007). Emigration and wages in source countries: Evidence from Mexico. Journal of Development Economics, 82(1), 180-199.

Mitra, R., \& Hossain, M. S. (2013). Foreign aid and economic growth in the Philippines. Economics Bulletin, 33(3), 1706-1714.

MM, A. (2016). What are the impact of foreign aid to the economic growth? Time series analysis with new evidence from Tanzania. Business and Economics Journal, 7(3). https://doi.org/10.4172/2151-6219.1000237

Morrissey, O. (2001). Does aid increase growth? Progress in Development Studies, 1(1), 37-50.

Mosley, E., Hudson, J., \& Horrel, S. (1987). Aid, the public sector and the market in less developed countries. Economic Journal, 97, 616-641.

Mujahid, N., Begum, A., \& Noman, M. (2016). Impact of trade on economic growth of Pakistan: An ARDL to co-integration approach. Journal of Social Sciences and Humanities.

Nelson, C. R., \& Plosser, C. I. (1982). Trends and random walks in macroeconomic time series. Journal of Monetary Economics, 10, 139-162.

Nkoro, E., \& Uko, A. K. (2016). Autoregressive Distributed Lag (ARDL) cointegration technique: application and interpretation. Journal of Statistical and Econometric Methods, 5(4), 63-91.

OECD. (1992). Review of the ODA concept note. Secretariat DCD/DAC(92)28.

Pakistan Economic Survey. (2017). Overview of the Economy. Government of Pakistan. http://www.finance.gov.pk/survey/chapters_18/overview_2017-18.pdf

Pesaran, M. H., \& Shin, Y. (1999). An autoregressive distributed lag modelling approach to cointegration analysis." Econometrics and economic theory in the 20th century. The Ragnar Frisch Centennial Symposium, Strom, S. (ed.) Cambridge University Press.

Phillips, P. C. B., \& Perron, P. (1988). Testing for unit roots in time series regression. Biometrika, 75, 3335-3346.

Rahnema, M., \& Bawtree, V. (1997). The post-development reader. University of Chicago Press. https://www.press.uchicago.edu/ucp/books/book/distributed/P/bo20851453.html

Rajan, R., \& Subramanian, A. (2008). Aid and growth: What does the cross-country evidence really show? The Review of Economics and Statistics, 90(4), 643-665.

Rist, G. (2007). Development as a buzzword. Development in Practice, 17(4-5), 485-491. https://doi.org/10.1080/09614520701469328

Romer, P. M. (1989). Human capital and growth: Theory and evidence (Working Paper No. 3173; Working Paper Series). National Bureau of Economic Research. https://doi.org/10.3386/w3173

Semančíková, J. (2016). Trade, trade openness and macroeconomic performance. Procedia - Social and Behavioral Sciences, 220, 407-416. https://doi.org/10.1016/j.sbspro.2016.05.515

Smith, A. (2008). The division of labour, in G. Argyrous and F. Stilwell (eds), Economics as a social science: Readings in political economy. Pluto Press, Sydney, 88-91.

Suwa-Eisenmann, A., \& Verdier, T. (2007). Aid and trade. Oxford Review of Economic Policy, 23, 481-507.

Taimur Hassan, R. (2013). Pakistan needs trade, investment not aid. The Express Tribune. https://tribune.com.pk/story/601630/country-needs-trade-investment-not-aid/

Toda, H. Y., \& Yamamoto, T. (1995). Statistical inference in vector autoregressions with possibly integrated processes. Journal of Econometrics, 66(1), 225-250. https://doi.org/10.1016/03044076(94)01616-8

Wamboye, E. (2012). Quantity or quality? Foreign aid implications on economic growth in least developed countries (No. 39518; MPRA Paper). University Library of Munich, Germany. https://ideas.repec.org/p/pra/mprapa/39518.html

Were, M. (2015). Differential effects of trade on economic growth and investment: A cross-country empirical investigation. Journal of African Trade, 2(1-2), 71-85. https://doi.org/10.1016/j.joat.2015.08.002

Wood, B. (1994). The place of the " $D$ " in OECD, and of OECD in the development field. Memo to DAC Permanent Representatives, February 22, held in OECD Archives, Paris. 
World Bank. (1998). The World Bank annual report 1998 (English). World Bank. https://documents.worldbank.org/en/publication/documents-reports/documentdetail

World Bank. (2018). Stronger open trade policies enable economic growth for all [Text/HTML]. World Bank. https://projects.worldbank.org/en/results/2018/04/03/stronger-open-tradepolicies-enables-economic-growth-for-all

WTO. (2019). Aid for trade global review 2019. Wto.Org. https://www.wto.org/english/tratop_e/devel_e/a4t_e/gr19_e/gr19_e.htm

WTO, OECD, W. (2011). Aid for trade at a glance 2011: Showing Results [Text]. https://www.oecdilibrary.org/development/aid-for-trade-at-a-glance-2011_9789264117471-en

Yiew, T.-H., \& Lau, E. (2018). Does foreign aid contribute to or impeded economic growth? Journal of International Studies, 11(3), 21-30. https://doi.org/10.14254/2071-8330.2018/11-3/2

Zahonogo, P. (2017). Trade and economic growth in developing countries: Evidence from subSaharan Africa. Journal of African Trade, 3(1-2), 41-56.

https://doi.org/10.1016/j.joat.2017.02.001 